\title{
MODEL OF IMPROVING HUMAN RESOURCE PERFORMANCE THROUGH SELF EFFICACY SOCIAL COMEPTENCE IN THE CONTEXT OF ISLAMIC WORK ETHICS
}

\author{
Wisnu Ardyanto ${ }^{1^{*}}$, Widodo $^{2^{*}}$
}

\footnotetext{
* Affiliation:

${ }^{1,2}$ Magister Management Program, Sultan Agung Islamic University Semarang wofy2nd@gmail.com
}

\begin{abstract}
:
This study aims to examine the effect of self efficacy and social competence on HR performance and in moderation of Islamic work ethic. The research problem is how to improve the performance of human resources through self efficacy and social competence with moderation of Islamic work ethic. The sampel of this research was the employees of the Department of Regional Finance of Semarang Regency consisting of 102 respondents. Regression analysis was done with Statistical Package Social Science (SPSS) software, and it was used also to analyze the data. The result of the analysis showed that self efficacy and social competence have a significant effect on HR performance with moderation of Islamic work ethic. These empirical findings indicate that self-efficacy has a significant effect on HR performance; Social competence has a significant effect on HR performance; social competence has significant effect on self efficacy; Islamic work ethic moderates the effect of competence on self efficacy; Islamic work ethic moderates the effect of self efficacy on HR performance; and Islamic work ethic moderates the effect of social competence on HR performance.
\end{abstract}

Keywords: Self Efficacy, Social Competence, Islamic Work Ethics and HR Performance

\section{INTRODUCTION}

An organization can be developed if it is supported by resources that are able to work in accordance with the needs of the company. This is because human resources have an active role to dominate in every activity undertaken in their organization. The organization will always perform management with professional management to improve the competence of its human resources. Therefore, a human resource needs to have self efficacy and social competence that is needed in his organization.

Organizations, both small and large scale, will consider human resources as an important factor in their progress. Human resources 
have an important role for business development undertaken by the organization. Essentially, the business world will grow when supported by qualified employees.

Employees in an organization have a function in every execution of duties that must be done, one of which is the function of service, where in government agencies service is one thing that must be filled by human resources to anyone who needs government services. If the services provided are not satisfactory, it will get a bad impression in the eyes of the people. This is what makes the good performance of human resources is needed in government agencies.

Human resource performance is affected by several factors one of which is self efficacy. Self efficacy is a high level of confidence of employees in completing the work on time. Therefore, it takes a social competence that can support the development of individual performance (Ogoemeka, 2014).

HR has an important role in running his company's wheels, HR needs to know how the company is able to achieve its goals. HR is an element that is able to move the company towards the positive to achieve what is expected. Company support is very important in encouraging human resources to improve the performance of the company through its performance. The company needs to provide appropriate rewards for stimulating HR to issue all of their ability to progress the company.

A person of human resources has important meaning for a company. Therefore the company must be able to maintain the level of satisfaction. A human resource who is satisfied with his work will show a positive attitude in working. Thus, the company needs to maintain employee satisfaction by providing optimal support. Human resources are satisfied with work which is the beginning of a very important success for the company (Robbins, 2016).

Self-efficacy is the self-confidence that a human resource has in accomplishing his job responsibilities. With a high level of trust, human resources are able to expend all their abilities to achieve the job target (Ogoemeka 2014). High self-efficacy from a human resource can encourage human resources to achieve company's goals. This is what causes high self-efficacy, which then will improve the performance of human resources.

Human resource performance is also influenced by social competence, in which a human resource must have good ability to maintain and build a long-term interaction of relationships through good cooperation with others as part of efforts to achieve a goal of oneself and organization. Jian and Wang, (2013) stated that human resources capable of establishing good communication with others are able to open up profitable cooperation for the company, even though the social competence is based on their capabilities and establishing cooperative relationships with others Ogoemeka, 2014).

This research was based on the existence of research gap, where Megan et al., (2007); and Wang and Noe, (2010) showed that self efficacy has a significant positive effect on HR performance, while Hsiu-Fen, (2013) showed that self efficacy has no significant effect on HR performance. Ogoemeka, (2014); and Mallinckrodt and Wei, (2015) showed that social competence has a significant positive effect on HR performance, while Kasler et al. (2013) showed that social competence has no significant effect on HR performance. 
Based on the problems in this research, then the phenomena of gap are as follows:

1. Staff of the Agency of Regional Finance of Semarang Regency is lack of initiative to establish relationships with colleagues in carrying out their work.

2. Low self-confidence of employees of the Agency of Regional Finance of Semarang Regency is due to the unfulfilled wishes and expectations of human resources and the unfavorable organizational climate. If human resources feel their wishes and expectations are fulfilled, it will make them to continue to be part of the organization, where it can improve self efficacy.

3. Leaders do not encourage subordinates to assume responsibility and practice what they say.

4. Attention of organization to employees' welfare is still lacking, so that employees are less enthusiastic in carrying out the work.

The formulation of the problem in this research was supported by the research gap which shows different result of previous research i.e. the result of Megan et al., (2007) and Ogoemeka (2014) study which showed that self efficacy and social competence can improve human resource performance, however Hsiu-Fen , (2013); and Kasler et al., (2013) showed that self efficacy and social competence are not significant to HR performance.

\section{LITERATURE REVIEW}

Ogoemeka, (2014) stated that employees who have strong self-efficacy are able to complete their work to be more leverage in accordance with company's target. A person with strong self-efficacy will feel good when he gets difficult job challenges. A strong sense of confidence will encourage human resources to achieve excellence for organizational progress (Ogoemeka, 2014). Self-efficacy is determined by the experience of a human resource motivated by good social competence and reinforced good work ethics that will have an impact on improving human resource performance. Ogoemeka, (2014) stated that the more self-efficacy, the higher the human resource performance. It can be formulated into hypothesis 1 as follow:

\section{H1: Self Efficacy has positive effect on HR Performance}

Levin et al. (2014) stated that a strong social competence possessed by human resources is able to increase their confidence to achieve optimal work result. Levin et al. (2014) indicated that the ability of social competence is able to increase the confidence of human resources that will ultimately has an impact on the improvement of human resource performance. In addition, Levin et al. (2014) found a significant positive influence of self-competence on HR performance.

\section{H2: Social Competence has positive effect on HR performance} H3: Social Competence has positive effect on self efficacy

Ali and Owaihan (2016) showed that good Islamic work ethic can moderate the effect of self efficacy and social competence in improving HR performance. Islamic work ethic according to Akli and Owaihan (2016) is an orientation that shapes and influences Muslim involvement and partisipation in his workplace. The Islamic work ethic views work as a way 
for the interests of the private, economy, social and psychology, to continue social prestige, in order to increase social prosperity and to strengthen faith. Ali and Owaihan (2016) showed that Islamic work ethic moderates the influence of self efficacy and social competence on HR performance.

H4a: Islamic Work Ethic Moderates the Effect of Social Competence on Self Efficacy H4b: Islamic Work Ethic Moderates the Effect of Self Efficacy on HR Performance H4c: Islamic Work Ethic Moderates the Effect of Social Competence on HR performance

Based on the explanation on the literature review, it can be described into theoretical framework as follow:

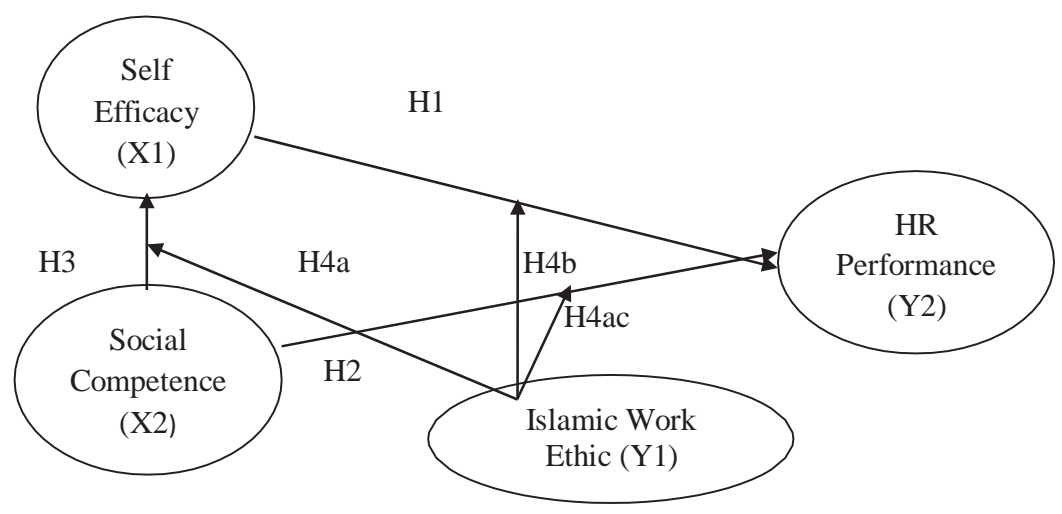

\section{RESEARCH METHOD}

Population is all available objects that exist in a study. The population in this research was the employees of BKUD of Semarang regency who are Moslem as many as 105. This research used census where all available populations become sample, so this research used the 105 responden. The analysis technique used in this research was moderating regression analysis (MRA) where to test the influence between variables, it used moderating variables.

\section{FINDINGS AND DISCUSSION Hypothesis Testing Equation 1}

To test hypothesis using t-test and f-test, regression analysis is needed. Linear regression analysis was used in this research with the aim to know whether there is influence of the independent variable (Imam Ghozali, 2001), namely: competence and moderation of Islamic work ethic towards self efficacy. The statistical calculations in the linear regression analysis used in the study employed the SPSS for Windows 11.0 computer program. The summary of data processing results using SPSS program are as follows: 
Table 1. Regression Result of Equation 1

Coefficients $^{\mathrm{a}}$

\begin{tabular}{|c|c|c|c|c|c|c|}
\hline \multirow[b]{2}{*}{ Model } & & \multicolumn{2}{|c|}{$\begin{array}{l}\text { Unstandardized } \\
\text { Coefficients }\end{array}$} & \multicolumn{3}{|c|}{$\begin{array}{l}\text { Standardized } \\
\text { Coefficients }\end{array}$} \\
\hline & & B & Std. Error & Beta & $\mathrm{t}$ & Sig. \\
\hline \multirow[t]{3}{*}{1} & (Constant) & .578 & .178 & & 3.254 & .002 \\
\hline & Competence & .766 & .096 & .766 & 7.999 & .000 \\
\hline & ModKIWE & .049 & .020 & .293 & 2.450 & .013 \\
\hline
\end{tabular}

a. Dependent Variable: Efficacy

Source: Calculated primary data, 2017

From table 4.1, a multiple linear regression can be arranged as follow:

Self efficacy $=0,766$ Competence $+0,049$ Competence*IWE

Coefficient of determination is a pointer about the magnitude of the influence of independent variables on the dependent variable. The coefficient of determination is shown by adjusted R2 value. The result of this research resulted adjusted R2 of 0,707. This indicates that $70.7 \%$ of self efficacy can be explained by social competence and Islamic work ethic, while the rest of $29.3 \%$ self efficacy is influenced by other variables not included in this model. This indicates that self efficacy is not only influenced by social competence and Islamic work ethic but there are other variables that influence self efficacy.

Table 2. Determination Coefficient

\begin{tabular}{lllll}
\hline Model & R & R Square & Adjusted R Square & $\begin{array}{l}\text { Std. Error } \\
\text { of the Estimate }\end{array}$ \\
\hline 1 & $.844^{\mathrm{a}}$ & .713 & .707 & .58025 \\
\hline
\end{tabular}

\section{the effect of Social Competence (X2) on Self efficacy (X1)}

The partial test of X2 variable (social competence) has a regression coefficient of 0.766 with a significance of 0.000 . The significance value is smaller than 0.05 indicating that social competence variable has a significant effect on self efficacy. The direction of positive regression coefficient indicates the positive influence of social competence on self efficacy. This indicates that employees who have high social competence have higher self efficacy.

\section{Islamic Work Ethic (Y1) Moderates the Effect of Social Competence (X2) on Self efficacy (X1)}

The partial test of Y1 variable (Islamic work ethic) has a regression coefficient of 0.293 with a significance of 0.013 . The significance value is smaller than 0.05 indicating that Islamic work ethic variable is able to moderate the influence of social competence on self efficacy. The direction of positive regression coefficient indicates the moderation of Islamic work ethic in strengthening the influence of social competence on self efficacy. This indicates that high Islamic work ethic is able to strengthen the influence of social competence on improving self efficacy better. 


\section{F Test}

The overall regression test was performed using $\mathrm{F}$ test. This test was performed using $5 \%$ significance level.

Table 3. Uji-F

ANOVA $^{\text {a }}$

\begin{tabular}{lllllll}
\hline Model & & $\begin{array}{l}\text { Sum of } \\
\text { Squares }\end{array}$ & df & Mean Square & F & Sig. \\
\hline 1 & Regression & 82.751 & 2 & 41.376 & 122.889 & $.000^{\mathrm{b}}$ \\
& Residual & 33.332 & 99 & .337 & & \\
& Total & 116.084 & 101 & & & \\
\hline
\end{tabular}

a. Dependent Variable: Efficacy

b. Predictors: (Constant), ModKIWE, Competence

The result of f-test test that examines the collective effect had an estimated F of 122.889 with a significance of 0.000 . This indicates that social competence and Islamic work ethic together have a positive influence on self efficacy, because the significance value is smaller than 0.05 . This shows that social competence and Islamic work ethic have a significant effect on self efficacy.

\section{Equation 2}

The summary of data processing results using SPSS program are as follows:

Table 4. Regression Result of Equation 2

\begin{tabular}{|c|c|c|c|c|c|c|}
\hline \multicolumn{7}{|c|}{ Coefficients $^{\mathrm{a}}$} \\
\hline & & $\begin{array}{l}\text { Unstan } \\
\text { Coeffic }\end{array}$ & ized & $\begin{array}{l}\text { Standardized } \\
\text { Coefficients }\end{array}$ & & \\
\hline \multicolumn{2}{|c|}{ Model } & B & Std. Error & Beta & $\mathrm{t}$ & Sig. \\
\hline \multirow[t]{5}{*}{1} & (Constant) & 1.798 & .169 & & 10.663 & .000 \\
\hline & Competence & .431 & .206 & .299 & 2.092 & .037 \\
\hline & Efficacy & .545 & .264 & .232 & 2.061 & .042 \\
\hline & ModKIWE & .223 & .087 & .427 & 2.563 & .018 \\
\hline & ModEIWE & .189 & .087 & .320 & 2.170 & .032 \\
\hline
\end{tabular}

a. Dependent Variable: KSDM

Source: Calculated primary data, 2017

Dari tabel 4. maka dapat disusun persamaan regresi linier berganda sebagai berikut:

HR performance $=0,431$ Competence $+0,545$ Self efficacy $+0,223$ Competence $*$ IWE + 0,189 Self efficacy*IWE

The coefficient of determination is a pointer about the magnitude of the influence of independent variable on the dependent variable. The coefficient of determination is shown by adjusted R2 value. The result of this research resulted adjusted R2 of 0,686. This indicates 
that $68.6 \%$ HR performance can be explained by social competence, Islamic work ethic and self efficacy while $31.4 \%$ HR performance is influenced by other variables not included in this model. This indicates that HR performance is not only influenced by social competence, Islamic work ethic and self efficacy but there are other variables that influence HR performance.

Table 5. Determination Coefficience

\begin{tabular}{lllll} 
& \multicolumn{4}{c}{ Model Summary $^{\mathbf{b}}$} \\
\hline Model & $\mathrm{R}$ & R Square & $\begin{array}{l}\text { Adjusted } \\
\text { Square }\end{array}$ & R \\
\hline 1 & $.836^{\mathrm{a}}$ & .698 & .686 & .51787 \\
\hline
\end{tabular}

a. Predictors: (Constant), ModEIWE, Competence, Efficacy, ModKIWE

b. Dependent Variable: KSDM

\section{The Effect of Social Competence (X2) on HR Performance (Y1)}

The partial test of X2 variable (social competence) had a regression coefficient of 0.299 with a significance of 0.037 . The value of significance is smaller than 0.05 indicates that social competence variable has a significant effect on HR performance. The direction of positive regression coefficient indicates a positive influence of social competence on HR performance. This indicates that employees who have high social competence have better HR performance.

\section{the effect of Self efficacy (X1) on Hr Performance (Y2)}

The partial test of $\mathrm{X} 1$ variable (self efficacy) resulted a regression coefficient of 0.232 with a significance of 0.042 . The value of significance is smaller than 0.05 indicating that the self efficacy variable has a significant effect on HR performance. The direction of positive regression coefficient indicates a positive effect of self efficacy on HR performance. This indicates that employees with high self efficacy have better HR performance.

\section{Islamic Work Ethic (Y1) Moderates the Effect of Social Competence (X2) on HR Performance (Y2)}

The partial test of Y1 variable (Islamic work ethic) had a regression coefficient of 0.427 with a significance of 0.018 . The value of significance id smaller than 0.05 indicating that Islamic work ethic variable is able to moderate the influence of social competence on HR performance. The direction of positive regression coefficient indicates the moderation of Islamic work ethic in strengthening the influence of social competence on HR performance. This indicates that high Islamic work ethic is able to strengthen the influence of social competence on improving HR performance better.

\section{islamic Work ethic (Y1) Moderates the effect of efficacy (X1) on $\mathrm{Hr}$ performance (Y2)}

The partial test of Y1 variable (Islamic work ethic) had a regression coefficient of 0.320 with a significance of 0.032 . The value of significance is smaller than 0.05 indicating that Islamic work ethic variable is able to moderate the effect of self efficacy on HR performance. 
The direction of positive regression coefficient indicates the moderation of Islamic work ethic in strengthening the influence of self efficacy on HR performance. This indicates that high Islamic work ethics can strengthen the influence of self efficacy on improving HR performance better.

\section{F Test}

The overall regression test was performed using F test. This test was performed using $5 \%$ significance level.

Table 6. F Test

ANOVA $^{\mathrm{a}}$

\begin{tabular}{|c|c|c|c|c|c|c|}
\hline Model & & Sum of Squares & df & $\begin{array}{l}\text { M e a } n \\
\text { Square }\end{array}$ & $\mathrm{F}$ & Sig. \\
\hline \multirow[t]{3}{*}{1} & Regression & 60.256 & 4 & 15.064 & 56.170 & $.000^{\mathrm{b}}$ \\
\hline & Residual & 26.014 & 97 & .268 & & \\
\hline & Total & 86.270 & 101 & & & \\
\hline
\end{tabular}

a. Dependent Variable: KSDM

b. Predictors: (Constant), ModEIWE, Competence, Efficacy, ModKIWE

The result of f-test test that examines the together effect has an estimated $\mathrm{F}$ of 56.170 with a significance of 0.000 . This indicates that Islamic work ethic, social competence, and self efficacy together have a positive influence on HR performance, meaning that the significance value is smaller than 0.05 . This shows that Islamic work ethic, social competence, and self efficacy have a significant effect on HR performance.

\section{CLOSING}

\section{Conclusion}

Based on the analysis result and discussion, it can be concluded as follows:

1. The result showed that self efficacy has a significant positive effect on the performance of human resources, meaning that the better self-efficacy the higher the performance of human resources. To improve the performance of human resources to the organization, they need to have high self-efficacy. In general, the pattern of self efficacy at the Agency of Regional Finance Semarang regency has not been in an ideal position meaning that there still needs improvement. The percentage of figures showing disagreement is still quite high. The weakest indicator of self-efficacy in improving the performance of human resources is an indicator of self-preparedness in accepting job risks, which means that employees need to put more emphasis on readiness in accepting job risks to improve human resource performance. Employees who have strong self efficacy can make them work well and quickly.

2. The result showed that social competence has a significant positive effect on the performance of human resources, meaning that the better the social competence, the better the performance of human resources. To improve the performance of human resources to 
the employees of the Agency of Regional Finance of Semarang Regency, it is necessary to improve social competence. The pattern of social competence in the Agency of Regional Finance of Semarang regency still needs improvement. The percentage of high enough disagreements to indicate a wide network of employment shows a weak indicator on social competence in improving human resource performance. It shows that employees are expected to be more emphasis by expanding work network so that the work can improve its performance that human resources have strong social competence to work well.

3. The results showed that social competence has a significant positive effect on self efficacy, which means that the better the social competence, the higher the self efficacy. The variable of social competence needs to be improved so as to improve self efficacy from the employees of the Agency of Regional Finance of Semarang Regency. Social competence in Regional Finance Agency of Semarang regency not yet an ideal position means that it is still need improvement repair. A high percentage of disapproval of broad employment network indicators shows as the weakest indicator of social competence in improving the performance of human resources, meaning that human resources at the Regional Finance Agency need to put more emphasis on a wide network of jobs that are capable of improve the performance of human resources.

4. The result showed that Islamic work ethic is able to strengthen the influence of self efficacy and social competence on human resource performance, meaning that the better work ethic, the higher self efficacy and social competence in improving the performance of human resources and is able to strengthen social competence in improving efficacy self. Islamic work ethic at the Agency of Regional Finance of Semarang regency has not been in an ideal position so that it still needs improvement. Considering the view that states disagreement, the figures indicate a fairly high percentage, and the indicators do not recognize job that is not in line with Islamic principles and teachings showing as the weakest indicator on Islamic work ethic in improving human resource performance and self efficacy. This shows that employees need to be more emphasized by understanding the work in accordance with Islamic principles and teachings so as to improve selfefficacy and human resource performance.

The formulation of the problem in this research is how social competence and self efficacy towards HR performance through the moderation of Islamic work ethic. Based on the hypotheses that have been developed in this study, the research problem that has been proposed can be justified through path analysis test which has been conceptualized through this research that self efficacy and social competence have a good role in improving HR performance which strengthens Islamic work ethic.

Based on the significant support of hypothesis testing, it has addressed the research problem, which results in 3 improvements of HR performance as follows:

- First, the steps in an effort to improve HR performance through self-efficacy is built by social competence.

- Secondly, the steps to improve HR performance through self efficacy are strengthened by Islamic work ethic

- Third, the steps to increase HR performance can be conducted through social competence. 


\section{MANAGERIAL IMPLICATION}

1. The Staff of Regional Finance Agency of Semarang Regency strengthens social competence by encouraging the employees to have good social competence. The employees of the Regional Finance Agency of Semarang Regency need to improve their social competence to improve their self efficacy and HR performance.

2. Staff of Regional Finance Agency of Semarang Regency needs to strengthen self efficacy, where the employees need more emphasis on high confidence which is able to complete the job well in order to improve HR performance. Employees who have a strong self efficacy to make employees have an increased performance.

\section{RESEARCH LIMITATION}

This research is conducted with some limitations and weaknesses as follows:

1. The analytical tool has not made a perfect contribution. The three variables of self efficacy, Islamic work ethic and social competence, contributed only 68.6\%. It means very likely there are still other variables that also affect the performance of Regional Financial Agency of Semarang Regency.

2. In conducting research at the Regional Financial Agency of Semarang Regency, the researcher conducted research only a few months so it does not rule out many shortcomings that exist in this study.

\section{FUTURE RESEARCH AGENDA}

1. Future research will be conducted not only on the staff of the Regional Financial Agency of Semarang Regency, but by investigating all employees in the Government of Semarang Regency. Further research is also expected to develop studies related to the efforts to improve HR performance.

2. Future research needs to add other variables that are expected to improve HR performance such as the role of organizational culture and intrinsic motivation.

\section{REFERENCE}

Ghozali, 2014. Aplikasi analisis Multivariate dengan Program SPSS. Badan Penerbit UNDIP, Semarang.

Hsiu Fen Lin, 2013. Knowledge donating and firm innovation capability: an empirical study. International Journal of Manpower

Jian, Zhaoquan; dan Chen Wang, 2013. The impact of network competence, knowledge donating on service innovation performance: moderating role of relationship quality. Journal of Industrial Engineering and Management

Kasler, Jonathan; Meirav Hen; dan Adi Sharabi Nov, 2013. Building emotional competence in educators. International Journal of Higher Education

Khan, Adalat, 2014. Islamic leadership principles. Mina Management Institute 
Levin, Daniel Z; Rob Cross; Lisa C Abrams; dan Eric L Lesser, 2014. Trust and Knowledge donating: A critical combination. IBM Institute for Knowledge Based Organizations

Mallinckrodt, Brent dan Meifen Wei, 2015. Attachment; social competencies; social support and psychological distress. Journal of Counselling Psychology

Megan Lee Endres; Steven P Endres; Sanjib K Chowdury; dan Intakhab Alam, 2007. Tacit knowledge donating, self efficacy theory and application to the open source community. Journal of Knowledge Management

Ogoemeka; Helen Obioma, 2014. Effects of peer collaboration on academic self efficacy belief and social competence of students with visual impairment. The Clute Institute International Academic Conference

Robbins, Stephen. 2016. Perilaku Organisasi. Prentice Hall. PT Indeks Kelompok Gramedia. Edisi Bahasa Indonesia. Edisi Kesepuluh

Sutton, Melanie. 2006. Emotional intelligence and competence in a knowledge citizen's world. South African Journal of Information Management.

Tarricone, P. \& Luca, J. (2002) Successful teamwork: A case study, in Quality Conversations, Proceedings of the 25th HERDSA Annual Conference, Perth, Western Australia. 